\title{
Identifying and Aligning Product 'Attributes' with Latent Consumer Purchase Motivations
}

\author{
Khairun Nisa Mustaffa Halabi ${ }^{1} \bowtie$ \\ David Hands ${ }^{2}$
}

${ }_{1,2}^{2}$ Lancaster Institute for the Contemporary Arts (LICA), Lancaster University, United Kingdom ${ }^{2}$ Email:nysamustaffa@yahoo.com

( Corresponding Author)

\begin{abstract}
The characteristics and elements of a product play a significant role as a medium to convey product value to consumers. This paper offers a theoretical reflection from numerous research case studies on the understanding of consumer purchase behaviour in engaging with a particular product's elements and characteristics and to explore consumers' emotional experience and perceptions to achieve the desired position in consumers' minds. This paper compares the perspectives of product attributes and consumer behaviour through discussing two theoretical models (behavioural perspective, purchase motivation, product attributes, product aesthetic) that are useful for an understanding of the functions of product attributes. Furthermore, this study emphasises aspects for markets and designers to contemplate in their efforts to increase consumer awareness and create the brand through their experiences and emotions. Finally, the implications of a stronger theoretical approach to consumer behaviour research and practice are discussed.
\end{abstract}

Keywords: Consumer behaviour, Perceived value, Purchase behaviour, Packaging design.

Citation | Khairun Nisa Mustaffa Halabi; David Hands (2018). Identifying and Aligning Product 'Attributes' with Latent Consumer Purchase Motivations. Asian Journal of Social Sciences and Management Studies, 5(1): 16-22.

History:

Received: 29 May 2017

Revised: 20 July 2017

Accepted. 13 December 2017

Published: 26 January 2018

Licensed: This work is licensed under a Creative Commons

Attribution 3.0 License (cc)

Publisher:Asian Online Journal Publishing Group
Contribution/Acknowledgement: Both authors contributed to the conception and design of the study.

Funding: This study received no specific financial support

Competing Interests: The authors declare that they have no conflict of interests.

Transparency: The authors confirm that the manuscript is an honest, accurate, and transparent account of the study was reported; that no vital features of the study have been omitted; and that any discrepancies from the study as planned have been explained.

Ethical: This study follows all ethical practices during writing.

\section{Contents}

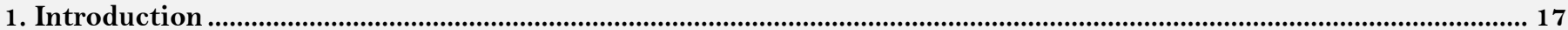

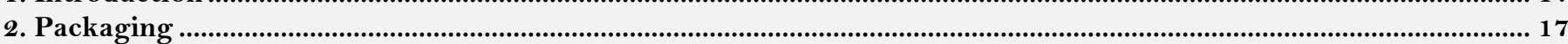

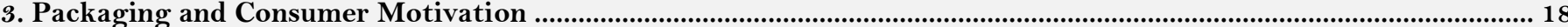

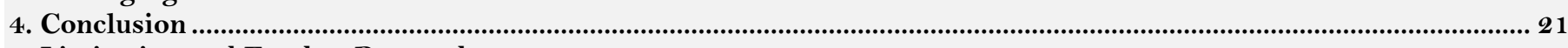

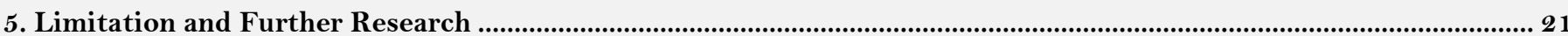

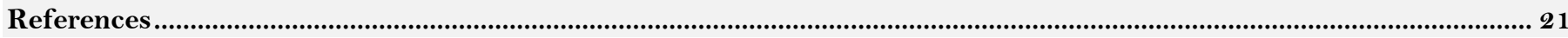




\section{Introduction}

Motivation is an acquired human behaviour, such as thoughts and feelings in the mind which prompt action in a certain way and depicted by conscious or unconscious decision processes (Nwankwo et al., 2014). The tangible product attributes motivate consumers to purchase a product with latent needs. The product attributes must fulfil the expectations to satisfy consumer desires and needs and are highly significant in getting consumers to perceive the product's essential values and are also an influential medium for consumers to assess the product values directly. The product attributes, features and other factors can influence consumer perceptions and behaviour and have an effect on their purchase decisions. Consumer motivation is a significant focus for marketers in determining a business strategy to create brand awareness and increase sales.

The paper sheds light on consumer understanding and motivation through the role of product attributes' effect on consumer behaviour in a purchase motivation context. The strategy for influencing consumer purchase decision leads to a discussion on various factors affecting purchase behaviour and motivations. The paper concludes with a conclusion of the results and suggestions for future research that may further an understanding of the topic of interest.

\section{Packaging}

Previous studies suggest that consumer motivation is often associated with product attributes, such as packaging design, in influencing consumer decision-making, brand awareness and individual perceived relevance. The intrinsic and extrinsic function of product plays a very important role in consumer assessment, which determines consumer judgement about product quality (Herrmann et al., 2000). Researchers have identified various factors associated with consumer purchase motivation: physical product elements, brand name and aesthetic features (Orth and Malkewitz, 2008; Noble and Kumar, 2010). However, as mentioned, the psychological ownership has an impact on the consumer' decision-making process and may affect the result of the final decision underlying the product's appearance (Fuchs et al., 2010).

\subsection{Packaging Attributes}

Packaging is an important medium in business marketing. The elements of packaging also have a significant impact on consumer purchase behaviour. There are various definitions of packaging.

Packaging is a significant tool for marketing and is used in generating competitive advantage for a business (Rundh, 2013). Westerman et al. (2013) emphasise that packaging is an interactive instrument at the point of sale that can communicate with consumers directly. The image of a brand affects consumer purchase intention and the decision-making process through the visual elements of packaging: shape, colour, orientation and graphics (Westerman et al., 2013). However, Rundh (2009) highlights that the packaging is particularly important and is considered as part of the product in terms of marketing; packaging elements are also significant to promote the brand and in effectively adding value to the product to fulfil consumer needs.

Marketers should distinguish the key packaging elements which need to be emphasised in terms of perceived consumer brand preferences, quality and value, such as colour, typeface, logo, graphics and size (Wang, 2013). The key factors can be identified as the following five packaging elements:

\subsubsection{Colour}

Colour is an integral element of corporate and marketing communications. It induces moods and emotions, influences consumer perceptions and behaviour and helps companies position or differentiate from the competition (Aslam, 2006). The colour of the packaging design stimulates consumer attention and the decision-making process. The specific choice of colour gives positive influence and associates to the consumer's favourable feelings (Wang, 2013). Colours can change the meaning of the objects or situations with which they are associated and colour preferences can predict consumer behavior (Aslam, 2006). Aslam (2006) also states that colours have great effects, also stimulate consumer responses based on feelings and associations. The success of packaging depends heavily on colour, which gives strong association to a specific brand when it is unique (Silayoi and Speece, 2004). In low decision involvement, colour is crucial when the evaluation of product attributes is insignificant (Grossman and Wisenblit, 1999).

\subsubsection{Typeface}

Package design has two important components, graphics (colour, typeface, logo), also structural elements (shape, size, materials) to indicate symbolism, because these product attributes can represent specific meanings in a culture (Underwood, 2003). A typeface can seek to change a specific desired consumer perception among different target of groups: upper class, middle class and lower class (Ampuero and Vila, 2006). The classification of typeface represents the product characteristics; for example, Roman typography, bold, large, letters with upper case and expanded characters associated with a packaging represent elegance, on the other hand, the typography of serif and sans serif are associated for reasonable price and accessible products (Ampuero and Vila, 2006). This shows that the typeface is capable of measuring marketing positioning strategy, by which it can transmit the desired perception to the consumers' minds (Blankson and Kalafatis, 2001).

\subsection{3. $\log 0$}

The logo is a significant attribute for consumers to identify and distinguish the product from other competitors, and is also a form of brand identifier and enhances brand personality (Rundh, 2009; Noble and Kumar, 2010). Sundar and Noseworthy (2014) emphasise that strategic logo placement on the packaging can capitalise on brands firmly established in the marketplace and the logo can evoke instant consumers' responses. On the other hand, Underwood (2003) argued that there is a significant interaction between the corporate and brand identity with consumers through the logo. The logo represents the brand's power and is viewed as a leader in positioning it 
above the consumer, which leads consumers to better evaluate the brand and then influence consumer perception of the social brand standing within its set of comparative (Huang et al., 2013).

\subsubsection{Graphics}

There is a significant correlation between the graphics of packaging and consumer purchase intention and motivation. Graphics, such as the packaging image, have an impact on positive attitude impact regarding packages, brands and consumer purchase intention (Olawepo and Ibojo, 2015). Underwood et al. (2001) pointed out that a images of product can increase consumer attention for brands especially brands that are unfamiliar, also communicate its experiential benefits to consumers. The visual package information creates positive imaging, which conveys the attributes desired from the product, leading to improved perceptions of these attributes, and elevated brand evaluations Underwood and Klein (2002). Figure 2.1 shows that the graphics on the packaging affect consumer attitude and stimulates their attention as regards either positive or negative information about the product. The product image sets certain expectations for the content of the product and consumers spontaneously elicit a positive evaluation of product, such as looks, taste, feel, smells or sounds (Underwood and Klein, 2002).
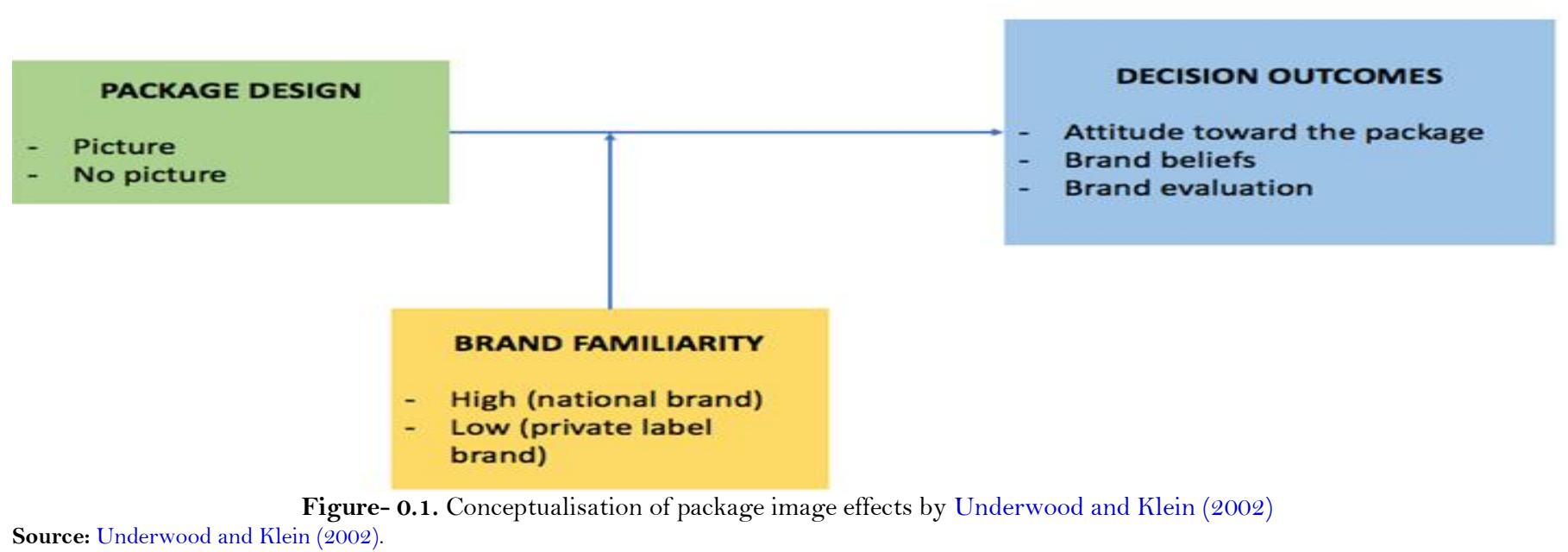

Source: Underwood and Klein (2002).

\subsubsection{Size}

According to Wansink (1996) size plays a significant role in consumers' product evaluation and that packaging size is the most significant ingredient to distinguish from other competition and in the market share (Rundh, 2009). Marketers should focus on with economic stagnation, since, as the public is aware of waste and overconsumption, the packaging size becomes a crucial element to avoid negative consumer response (Ordabayeva and Chandon, 2013). Therefore, marketers need to understand that size can bias a consumer's impression and preferences.

\section{Packaging and Consumer Motivation}

The role of a product is to communicate with consumers through its physical attributes. The physical attributes aim to attract consumers' attention, perception and stimulate their purchase motivation. The 'aesthetic' is the term most commonly related to the appearance of a product and which hold the consumers' symbolic values (Crilly et al., 2004). The use of aesthetic features in product design has a significant influence on consumer perception and purchase motivation.

The development of product attributes generates a massive impact and influences aesthetic assurance in human lives and concerns. Hung and Chen (2012) stated that consumers' perceptions are influenced by three significant fundamental dimensions in terms of aesthetic preferences: (1) trendiness, (2) complexity and (3) emotion. These dimensions have a specific contribution in influencing consumer perception towards a product's aesthetic design. However, Bloch (1995) points out that the 'prevailing styles and fashion' have strong implications for consumer perception and emotion and change in their product preferences. Moreover, Blijlevens et al. (2009) support the argument that product complexity is an important aspect in motivating consumer purchase preferences and stimulating purchase intention. The product complexity corresponds to the simplicity or complexity of the product's design elements (Hung and Chen, 2012). In the context of emotions, consumers' reactions and feelings are affected by the visual product aesthetic. It is significant for a product to be adequate in the selection process in consumers' minds.

Further, Marinkovic et al. (2012) argue that the product aesthetic is significant in that it can trigger consumer satisfaction and establish a psychological attachment to the consumer. They highlight that an object without a good design is incomplete and becomes invisible to the consumers' eyes because they see it as an incomplete product with no design elements or characteristics. In order to gain consumer appreciation value towards product design, it is important to have a knowledge of the social, cultural and historical elements involved in the product's features and its functional quality to stimulate consumer motivations.

Nevertheless, Forsey (2013) argues that product aesthetic cannot be seen through a simple direct observation, but through the product's features and functions. The product features quality represents the 'functional' and the more 'attractive' in the context of 'fit form' with the surrounding environment. Consumer consumption behaviour changing through interaction with product design reveals social and cultural values according to by Bhamra et al. (2011). The solicited opinions, perceptions and beliefs are an effective combination in stimulating consumer behaviour due to continuously changing social norms.

Consumer expectation is not only emphasised on product aesthetic preferences, but also how they perceive product images in the display (Law et al., 2012). In this context, product aesthetic values are stimulating by the use of an overall pleasant image to enhance consumers' cognitive and affective responses. The purchase decision response is stimulated by the aesthetic and symbolic features of function-oriented products. The process of 
communication between designers and consumers is accessible in the visual domain in product form. Consumer responses are affected by its functionality and represent the owner's personality (Crilly et al., 2004). The product forms quality elements, and provides semantic interpretations, symbolic associations and aesthetic impression.

\subsection{Factors Influencing the Decision-Making Process}

The packaging design will foster different levels of consumer perceptions. The product designer needs to create an overall product quality with an attractive product image in order to create emotional value, simplicity, recollection and technological assurance in creating a sophisticated product for consumers. The first impression of a consumer's judgement is the significant style of the product's visual appearance.

Underwood et al. (2001) highlight that consumer decision-making is influenced by the various elements of packaging and the decision is dependent on packaging elements which induce positive feelings intrinsically associated with the product. The correlation between the elements of package design and consumer response is important for marketers to understand that how consumers perceive the product appearance has a significant impact on consumer purchase behaviour. The relevant product elements can trigger consumers' pleasure and simulation feelings and have an impact on their perceptions (Bloch, 1995). The visual domain, in the form of product, creates psychological responses, which include both cognitive and affective aspects (Bloch, 1995; Crilly et al., 2004). In the context of consumption, consumer response to the visual of a product form which is moderated by particular previous experiences increases the product's attraction. Despite the importance of the visual appeal to business, the visual references may also be affected by the individual's experience and personality traits. The experience is created by the consumer's cognitive response and associates with memories and cultural facts (Crilly et al., 2009).

Furthermore, packaging is also associated with consumer purchase decisions; products presented in appealing packaging can influence consumer choice and is a key element of marketing strategy success (Gofman et al., 2010). Furthermore, an attractive packaging conveys messages to consumers in promoting products and the package attributes make the product more noticeable and, thereby, enhance brand awareness to consumers. A distinctive package design communicates with consumers in the form of unique attributes to influence their judgement and purchase decision as well as to represent the overall strength of brand value in the market (Ahmed et al., 2014).

The aesthetic of packaging components, such as the graphics, shape, colour, size and typography, plays an important role in product differentiation in order to influence consumers' product preferences and to trigger consumer purchase intention (Ampuero and Vila, 2006; Wang, 2013). Also, Geistfeld et al. (1977) stated that consumers perceive product's characteristics by using its appearance factors in order to differentiate the physical properties that underlie the product's appearance. Consumers perceive product appearance value through its appearance factors, such as visual design and physical characteristics. The product and package design is a superior medium for manufacturers to convey brand personalities and impressions (Orth and Malkewitz, 2008).

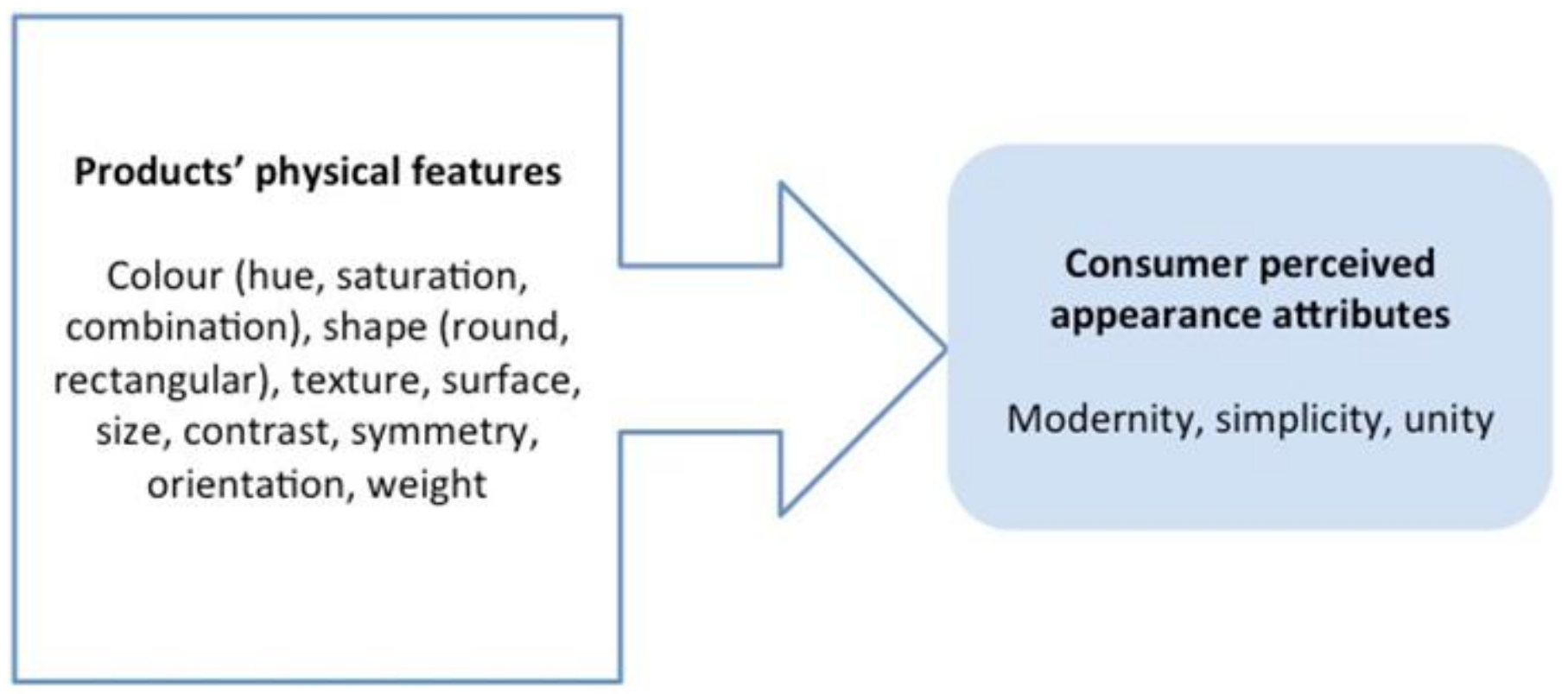

Figure-0.1. A two-step model of consumer perception towards product attributes (as cited in Blijlevens et al. (2009)) Source: Blijlevens et al. (2009).

Blijlevens et al. (2009) point out that product appearance perception by consumers can be assessed in two ways, physical properties and other physical attributes. The combination of colour, shape, texture, materials and other physical features can define a product's individuality to meet consumer preference needs (Figure 3.1). It's an overall perception view on how the consumer perceives value to distinguish some product attributes from others at a quick glance.

Today's product is mainly perceived by consumers through its visual aesthetic. Consumers use alternative symbolic meaning to describe the aesthetic of product appearance due to a lack of design knowledge. The consumer's acceptance is critical for a product's sensory evaluation by which they describe the product's characteristics using specific subjects or terms, such as playful, rugged, simplicity and modern. The perception value can create a stronger brand affection and influence of brand identification on brand loyalty within consumers (Kumar et al., 2014).

However, Bloch (1995) asserts that, in a design goals context, the performance aspiration goals should greatly influence consumers. The design elements increasingly influence consumers' visual perceptions and the perceived product value as a whole. Figure 3.2 shows the combinations of engineering, art, psychology and ethology are significant elements in consumer marketing in the context of psychological and behavioural reactions (Bloch, 
1995). Bloch (1995) emphasised that consumers perceived the product form value through tangible and intangible factors whereby all elements merged as a visual whole. Bloch pointed out that consumer responses to product form constrained their preferences and tastes from one product to another; hence the product needs to be visually attractive to evoke their emotional desires and influence their purchase decision motivations.

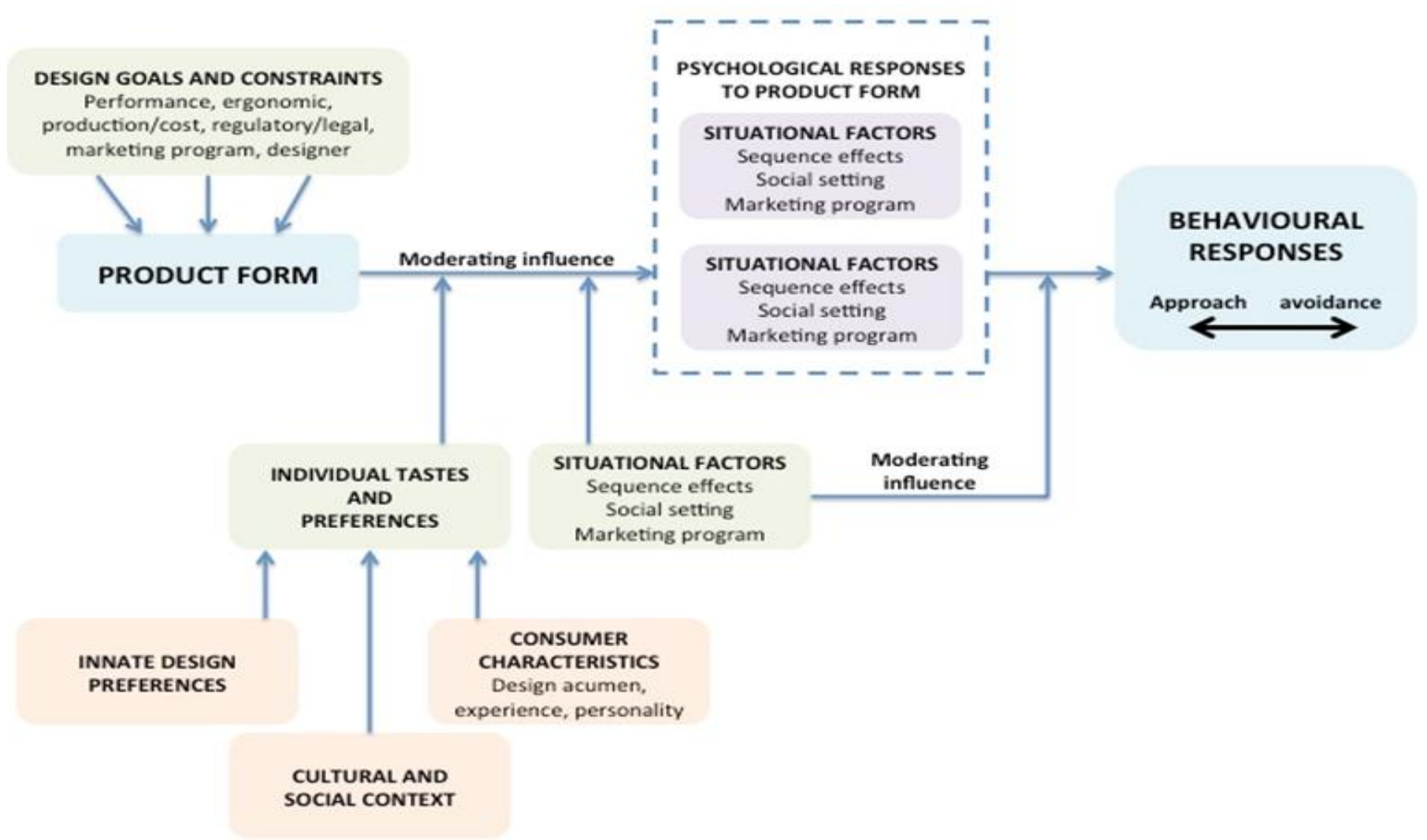

Source: Bloch (1995)

Figure-0.2. A model of consumer responses to product form (Bloch, 1995)

The previous section articulated that the product quality appearances encourage consumers' emotional attachment development and that consumers perceived the design details within their environment as well as how consumers observe and are attracted by the product presentation. However, this model has neglected the designers' intention on how to consider how a product will be experienced (Crilly et al., 2004). Crilly et al. (2004) argued that the product attributes are also influenced by three aspects, cognition, affect and behaviour, which manipulate consumer perceptions, besides the visual packaging attributes factors. Crilly et al. (2004) pointed out that a product's visual appearance is valuable in developing and understanding consumer requirements and quality-of-life and that the consumers' product judgements and decision-making process are influenced by both product appearance and their subjective experiences. Designers also play a significant role in finding a strategic brand identity to create the visual intention for consumers (Person et al., 2008).

The product visual aesthetic appearance is significant in determining consumers' aesthetic evaluation and encouraging positive impression. Kumar and Noble (2015) assert that theme values, such as social, altruistic value, functional and aesthetic, are significant factors in meeting consumers' buying perception regarding product design. Product design values are defined by a better interpretation in identifying the product's dimension through comprehensive evaluation within consumer value. Designers must consider the ergonomics and human-factor elements which drive consumers' perceptions in the context of a product's functionality and efficiency.

\subsection{Packaging Attributes Determinants of Consumer Purchase Behaviour}

This section discusses how packaging attributes can affect consumer purchase behaviour and decision-making process. The discussion addresses the important five packaging attributes.

In comparing the theoretical and existing models to form a broad and articulate perspective within the context of product appearance perspective, this study identifies that how consumers perceive product values contributes significantly to the success of a company's marketing strategy. The framework shows the extent to which researchers agreed that product attributes are significant factors to gain an insight and understanding of consumer needs and desires. The success of a product is measured based on how consumers value the quality of product and the visual packaging appearances, which are a powerful influence on consumer purchase motivation. This study points out that the product attributes change consumer behaviour and affect their intangible image perceptions.

From this point of view, the designer can use an analytical model to get a direction for the design approach and outcome of the process. It is significant for the marketers and designers to develop and maintain the brand strategy to meet consumers' needs and desires. In order to establish a greater understanding of consumer choice of product, it would be a mistake to ignore the greater subject of the package design attributes roles of new product evolution and market success. In addition, a qualitative research approach will be used that allows constructing a model based on the fundamental descriptions. Furthermore, we aim to determine how additional product attributes can be achieved, such as optimisation of deeper analytical product appearances performance to motivate consumer purchase intention, and also to what extent the effects of a product's design elements, such as graphics, shapes, sizes, typeface and colours, influences consumer purchase orientation as an 'attention-grabbing' product.

Furthermore, the final product design achievement is driven by efforts of designers in determining how a product will be experienced to correspond with consumers' responses (Person et al., 2008). Hence, the marketers need to understand that the product form and attributes are not the only factors that can influence consumers' 
intentions, but other various factors which can influence consumer purchase intention and shape the products should also be taken into account (Tovey, 1997).

\section{Conclusion}

This review observed that product attributes are attached to brand values so as to suit consumers' tastes and wants (Blijlevens et al., 2009). However, the consumers perceived value comes from not only physical attributes, but also how the product satisfies their needs and desires on many levels (Kumar and Noble, 2016). The evolution of product development is defined as a process of designers and manufacturers responding to opportunity and demand in creating a new product. There are strong interactions between product design manipulating in the context of consumers' assessments and purchase decisions. Despite a product being designed for creating a simpler life, the purpose of the product is in stimulating people's experience, attitude or behavior (Da Silva et al., 2015). Consumers engage with product aesthetic values by how they perceive their intentions related to their personal and social values.

In summary, this paper yields several important insights. Firstly, this paper emphasises the designers and marketers' concerns in the context of mass-market aesthetic sensibilities in clarifying product attributes that affect consumer purchase motivations. As such, five important packaging attributes, colour, typeface, logo, graphics and size, are recommended to marketers in developing a new product and understanding consumer responses to their packages to achieve brand success in the marketplace. Moreover, other intervening factors, such as culture, society, beliefs and the environment can also influence consumer attitude and alter their purchase decision. The results show strong internal and external factors influence in response to packaging. This suggests that the packaging design is expected to enhance consumers' expectations, judgements and perceptions towards product quality. Therefore, marketers should convey clear product information, specific colours and shapes and follow specific segments to fulfil consumers' needs and desires.

The correlation between consumer purchase motivation and packaging design is a significant issue that marketers must understand and give attention in order to develop effective marketing strategies, including uncovering a product's unique selling point. The packaging design is important in enhancing consumer-perceived product value and brand preferences and attracting consumers at the point of sale. Certainly, more research is needed in this area.

\section{Limitation and Further Research}

The aim of this study was to determine the factors that affect consumer purchase motivation from product attributes. The research process of identifying and supporting product attributes that motivate consumer purchase behaviour is underlined by a number of theory approaches. Thus, further research is called for and primary research will be carried out which comprises of original and new data collected by the research to define the timeframe, human behaviour, perceptions and product attributes which motivate purchase intention. It will address question such as: 'What is the effect of package design attributes on building brand awareness and how does it have an impact on brand image?'

Second, future research could explore the subtle relationships between societal and environmental considerations on conscious consumer behaviour. For example, the symbiotic interaction between consumers and packaging that can trigger consumers to purchase the product including influence the process of decision-making. It is possible that the elements of product packaging are significant in communicating the value of product whilst building brand impressions with consumers for corporations striving to maximise innovation solutions in productivity and consumption value for the product through packaging.

Third, an important difference should be made in exploring different packaging systems that have an impact on the societal and environmental consciousness within consumers. For example, the positioning of the packaging is competent of manipulating the brand identity, also strengthening the relationship between brand and consumers. The functional packaging elements have strong influence on consumer cognition, attitude and behaviour. Therefore, further research is required to investigate the distinctions in various contexts of consumer awareness.

There are certain other limitations which also bear mentioning. We only explored the influence of five packaging attributes and other underlying factors, such as social media, quality, consumer preferences and expectations, could also play a role in changing consumer purchase behaviour and motivation.

\section{References}

Ahmed, R.R., V. Parmar and M.A. Amin, 2014. Impact of product packaging on consumer's buying behavior. European Journal of Scientific Research, 120(2): 145-157. View at Google Scholar | View at Publisher

Ampuero, O. and N. Vila, 2006. Consumer perceptions of product packaging. Journal of Consumer Marketing, 23(2): 100-1 12. View at Google Scholar $\mid$ View at Publisher

Aslam, M.M., 2006. Are you selling the right colour? A cross-cultural review of colour as a marketing cue. Journal of Marketing Communications, 12(1): 15-30. View at Google Scholar | View at Publisher

Bhamra, T., D. Lilley and T. Tang, 2011. Design for sustainable behaviour: Using products to change consumer behaviour. Design Journal, 14(4): 427-445. View at Google Scholar | View at Publisher

Blankson, C. and S. Kalafatis, 2001. The development and validation of a scale measuring consumer/customer-derived generic typology of positioning strategies. Journal of Marketing Theory and Practice, 9(2): 35-53. View at Google Scholar $\mid$ View at Publisher

Blijlevens, J., M.E.H. Creusen and J.P.L. Schoormans, 2009. How consumers perceive product appearance: The identification of three product appearance attributes. International Journal of Design, 3(3): 27-35. View at Google Scholar

Bloch, P.H., 1995. Seeking design and the product form: Ideal consumer response. Journal of Marketing, 59(3): 16-29. View at Google Scholar | View at Publisher

Crilly, N., J. Moultrie and P.J. Clarkson, 2004. Seeing things: Consumer response to the visual domain in product design. Design Studies, 25(6): 547-577. View at Google Scholar | View at Publisher

Crilly, N., J. Moultrie and P.J. Clarkson, 2009. Shaping things: Intended consumer response and the other determinants of product form. Design Studies, 30(3): 224-254. View at Google Scholar $\mid$ View at Publisher

Da Silva, O., N. Crilly and P. Hekkert, 2015. How people's appreciation of products is affected by their knowledge of the designers' intentions. International Journal of Design, 9(2): 21-33. View at Google Scholar

Forsey, J., 2013. The aesthetics of design. New York: Oxford University Press. 
Fuchs, C., E. Prandelli and M. Schreier, 2010. The psychological effects of empowerment strategies on consumers' product demand. Journal of Marketing, 74(1): 65-79. View at Google Scholar | View at Publisher

Geistfeld, L.V., G.B. Sproles and S.B. Badenhop, 1977. The concept and measurement of a hierarchy of product characteristics. Advances in Consumer Research, 4(1): 302-307. View at Google Scholar

Gofman, A., H.R. Moskowitz and T. Mets, 2010. Accelerating structured consumer-driven package design. Journal of Consumer Marketing, 27(2): 157-168. View at Google Scholar | View at Publisher

Grossman, R.P. and J.Z. Wisenblit, 1999. What we know about consumers' color choices. Journal of Marketing Practice: Applied Marketing Science, 5(3): 78-88. View at Google Scholar | View at Publisher

Herrmann, A., F. Huber and C. Braunstein, 2000. Market-driven product and service design: Bridging the gap between customer needs, quality management, and customer satisfaction. International Journal of Production Economics, 66(1): 77-96. View at Google Scholar 1 View at Publisher

Huang, X., X. Li and M. Zhang, 2013. Seeing' the social roles of brands: How physical positioning influences brand evaluation. Journal of Consumer Psychology, 23(4): 509-514. View at Google Scholar $\mid$ View at Publisher

Hung, W.K. and L.L. Chen, 2012. Effects of novelty and its dimensions on aesthetic preference in product design. International Journal of Design, 6(2): 81-90. View at Google Scholar

Kumar, M. and C.H. Noble, 2015. Beyond form and function: Why do consumers value product design? Journal of Business Research. View at Publisher

Kumar, M. and C.H. Noble, 2016. Beyond form and function: Why do consumers value product design? Journal of Business Research, 69(2): 613-620. View at Google Scholar | View at Publisher

Kumar, M., J.D. Townsend and D.W. Vorhies, 2014. Enhancing consumers' affection for a brand using product design. Journal of Product Innovation Management, 32(5): 716-730. View at Google Scholar $\mid$ View at Publisher

Law, D., C. Wong and J. Yip, 2012. How does visual merchandising affect consumer affective response? An intimate apparel experience. European Journal of Marketing, 46(1/2): 112-133. View at Google Scholar $\mid$ View at Publisher

Marinković, V., S. Vladimir, S. Obradović and S. Šapić, 2012. Understanding antecedents of customer satisfaction and word-of-mouth communication: Evidence from hypermarket chains. African Journal of Business Management, 6(29): 8515-8524. View at Google Scholar $\mid$ View at Publisher

Noble, C.H. and M. Kumar, 2010. Exploring the appeal of product design: A grounded, value-based model of key design elements and relationships. Journal of Product Innovation Management, 27(5): 640-657. View at Google Scholar | View at Publisher

Nwankwo, S., N. Hamelin and M. Khaled, 2014. Consumer values, motivation and purchase intention for luxury goods. Journal of Retailing and Consumer Services, $21(5):$ 735-744. View at Google Scholar | View at Publisher

Olawepo, T. and O. Ibojo, 2015. The relationship between packaging and consumers purchase intention : A case study of Nestlé Nigeria product. International Business Management, 10(1): 72-81. View at Google Scholar | View at Publisher

Ordabayeva, N. and P. Chandon, 2013. Predicting and managing consumers' package size impressions. Journal of Marketing, 77(5): 123-137. View at Google Scholar | View at Publisher

Orth, U.R. and K. Malkewitz, 2008. Holistic package design and consumer brand impressions. Journal of Marketing, 72(3): 64-81. View at Google Scholar | View at Publisher

Person, O., J. Schoormans, D. Snelders and T.M. Karjalainen, 2008. Should new products look similar or different? The influence of the market environment on strategic product styling. Design Studies, 29(1): 30-48. View at Google Scholar $\mid$ View at Publisher

Rundh, B., 2009. Packaging design: Creating competitive advantage with product packaging. British Food Journal, 111(9): 988-1002. View at Google Scholar $\mid$ View at Publisher

Rundh, B., 2013. Linking packaging to marketing: How packaging is influencing the marketing strategy. British Food Journal, 115(11): 1547-1563. View at Google Scholar $\mid$ View at Publisher

Silayoi, P. and M. Speece, 2004. Packaging and purchase decisions: An exploratory study on the impact of involvement level and time pressure. British Food Journal, 106(8): 607-628. View at Google Scholar $\mid$ View at Publisher

Sundar, A. and T.J. Noseworthy, 2014. Place the logo high or low? Using conceptual metaphors of power in packaging design. Journal of Marketing Association, 78(5): 138-151. View at Google Scholar | View at Publisher

Tovey, M., 1997. Styling and design: Intuition and analysis in industrial design. Design Studies, 18(1): 5-31. View at Google Scholar $\mid$ View at Publisher

Underwood, R.L., 2003. The communicative power of product packaging: Creating brand identity via lived and via lived and mediated experience. Journal of Marketing Theory and Practice, 11(1): 62-76. View at Google Scholar | View at Publisher

Underwood, R.L. and N.M. Klein, 2002. Packaging as brand communication: Effects of product pictures on consumer responses to the package and brand. Journal of Marketing Theory and Practice, 10(4): 58-68. View at Google Scholar | View at Publisher

Underwood, R.L., N.M. Klein and R.R. Burke, 2001. Packaging communication: Attentional effects of product imagery. Journal of Product and Brand Management, 10(7): 403-422. View at Google Scholar | View at Publisher

Wang, E., 2013. The influence of visual packaging design on perceived food product quality, value, and brand preference. International Journal of Retail \& Distribution Management, 41(10): 805-816. View at Google Scholar | View at Publisher

Wansink, B., 1996. Can package size accelerate usage volume? Journal of Marketing, 60(3): 1-14. View at Google Scholar $\mid$ View at Publisher

Westerman, S.J., E.J. Sutherland, P.H. Gardner, N. Baig, C. Critchley, C. Hickey and Z. Zervos, 2013. The design of consumer packaging: Effects of manipulations of shape, orientation, and alignment of graphical forms on consumers' assessments. Food Quality and Preference, 27(1): 8-17. View at Google Scholar | View at Publisher 